\title{
Research on Evolution and Development of the Central Bank in Manchukuo
}

\author{
Xin Guan ${ }^{1, \text { a }}$ \\ ${ }^{1}$ Institute of Finance, Harbin University of Commerce, Harbin, Heilongjiang,150028 \\ aemail,
}

Keywords: Central Bank in Manchukuo, Finance, Aggression

\begin{abstract}
After the "Mukden Incident ", Japan made efforts to develop economic plunder policy in northeast China. On July 1st of 1932, the central bank of Manchukuo was born under the aegis of the Japanese Kwantung Army. In its existing fourteen years, the central bank of Manchukuo conducted a frenzied financial plunder in Northeast China under the control of the Kwantung Army, monopolized and controlled the Northeast's economic lifeline, refueled and transfusion for the Japanese aggression war. The construction and devolvement of the central bank of Manchukuo exposed the cruel and evil nature of Japanese financial invasion of northeast China from one side.
\end{abstract}

\section{The Statement of Problem}

"Aggression" is not a concept that needs to be defined academically, but needs the "History" to prove the irony fact. Japan committed heinous crimes and that cannot be covered by the "smart" definition. Japan's aggression against China, in addition to military occupation, it went further in its tireless various economic and financial control and plunder. After the "Mukden Incident", the Japanese took occupation of Shenyang, Changchun, Jilin, Qiqihar and other cities, in order to manipulate the Northeast's economic lifeline, it naturally first to win the Chinese major financial institution - "four banks." The next day of "Mukden Incident", the Japanese Imperial Army occupied the Northeast Official Bank by heavily armed troops, robbed the side banks; September 21, when the Japanese invaded Jilin, it closed Jilin Yongheng official bank; November 9, when the Japanese invaded Qiqihar, it closed the official bank in Heilongjiang province. At the same time, the Kwantung Army also seized the Bank of China, Bank of Communications and other financial institutions in the Northeast and set up so-called "Financial Research" in Shenyang and took complete control of financial institutions in northeast. In order to meet the needs of economic and financial aggression, the Japanese Kwantung Army set up a "rule section" by the ministry, with the South Manchurian Railway Company to jointly plan for the establishment of the Central Bank of Manchukuo. On July 1st 1932, the Central Bank of the Manchukuo by the Japanese single-handedly planned and the absolute leadership was established, from now on opened a prelude to the financial plunder to Northeast China, it gone through the three crashes phases of foundation laid, business expansion, destruction (establishing, strengthen and crash of the status of financial control)in fourteen years to meet the financial support of the Japanese military aggression.

\section{The Formation of the Financial Control System}

On July 1st of 1932, the128 total bank and branch bank of puppet Manchukuo central bank opened, manipulate the financial power of northeast. On March 1st, 1933, the Manchukuo Government issued "Manchukuo Economic Construction Program," and proposed to impose economic control policy in Manchukuo to make the Northeast economy completely reduced to the Japanese imperialist economic dependency. After this "Outline" officially announced, according to the relevant requirements of "Manchukuo Economic Construction Program," the central bank of the puppet Manchukuo imposed a series of coercive measures such as "regulate finance", "unified currency" and so on. Mainly: collect the various currencies in circulation in the market inthe original deadline in order to "unified currency"; the and gradually transferred the 22 kinds of ancillary enterprises looting forced from the "24 banks" to the newly established professional 
monopoly business; forced Chinese-owned banks, banks to increase capital, forced by the sole proprietorship into a limited company to carry out financial, personnel create conditions for penetration. At the same time, they set up rural financial cooperatives in rural areas by landlords, rich peasants as the pillar in order to facilitate its control of the rural financial markets.

In the collection of the market circulation "old money", the central bank of puppet Manchukuo of regime the dollar price down intentionally. 50 yuan "Feng Da-yang ticket "and "Ji Xiao-yang ticket", 60 "copper vote" respectively in order to redeem 1 Manchukuo currency. Especially the "official post" parity will be even lower, 500 official posts hanging against 1Manchukuo currency, down the official price by nearly 30\% against the post. Ji Lin Yongheng official note was in circulation amounted to more than 10.3 billion cranes, namely the people of the Northeast alone exploit counterfeit 800 million. During the unified currency, Japanese re-evaluation of the original "four banks" of assets and liabilities intends to depress its assets to expand its liabilities and fake the loss of "four banks" is 33 million yuan. Puppet government then submitted to cover losses in the name issue of "compensation bonds" 33 million yuan, the Japanese groan a huge amount of wealth. When redemption currencies original "four-line number" issued Manchukuo government claimed that "four lines of numbers" should be equivalent to a total of counterfeit banknotes 1.4223 billion. August 1935 to the end of the collection, they recovered 1.3821 million, up 4.02 million yuan unrecovered portion, then Rehe exchange coupon of 26.6\%, $7 \%$ horse Ocean votes, 51 percent did not recover copper votes figure included digital enormous. This wealth and income are for the puppet. In addition, while the redemption of the Japanese grab a lot of gold and silver.

In 1932--1936 years, the central bank of puppet Manchuria monopolized the finance of northeast through a series of stringent measures, initially established the foundation of the colony financial system, it laid the foundation for further large-scale invasion of Japan.

\section{The Strengthening Era of Financial Control System}

In 1937--1941 years, Japanese imperialists planned large-scale looting of strategic materials, expand its war of aggression and made Northeast China into the material supply base. Japanese imperialism implemented the so-called "three policies of the puppet Manchukuo State" during this period - "The First Five-Year Plan Industry Development ", "Million Immigrants Plan" and "North Revitalization Plan". For the successful implementation of the three plans, in the meantime, the central bank of puppet Manchuria make every effort to use monetary, credit and even administrative measures to vigorously support monopolies, industrial development, wealth plunder, pillage resources to support the full invasion of China. According to the puppet Manchukuo "National Mobilization Law", "Temporary Funds Control Law" and the "Banking Law", the central bank of Puppet Manchuria focused on every possible power of concentration to further strengthen the financial sector control from all angles, control of funds in various activities in support of the war of aggression against China.

In January of 1937, the Japanese implemented the "The Five-Year Plan of Industrial Development", the supply of long-term industrial finance business, controlled and operated by the Japanese, Korean, Cheng Loong, Manchuria Third Bank merger puppet Manchuria Industrial Bank. Pseudo Manchuria Industrial Bank actively cultivated professional monopolies, carrying out industrial "development", plunder resources. Puppet government to intensify plunder of wealth, also in December 1939 announced the "savings portion Act" for the Japanese imperialist aggression amassed funds. For this reason the central bank puppet Manchuria ad hoc savings portion, for organs and units of workers, the public, farmers' personal deposits and bonds issues. At the same time according to the revised "Exchange Management Law", the implementation of centralized foreign currency and to implement Puppet "exchange rate unification"; the establishment of "temporary exchange committee" to determine the use of the highest exchange rate policy, its executive bodies for the temporary exchange bureau, located in the center of the puppet Manchukuo a bank head office by the president and the Secretary.

With the development and changes in the current situation, in this period, the Central Bank of the puppet Manchuria handling general banking business greatly reduced, the issuing bank and 
financial control functions has dominated nature of the executive authorities increasingly significant. Puppet Manchuria central bank opened the first few years, the implementation of a tight monetary policy, to the end of 1935 the amount of the currency increased by only 31\% compared to the end of 1932151 million yuan. After 1936, counterfeit money circulation was increased significantly by the end of 1941 issuance volume reached 1.317 billion yuan, an increase of 8 times more than in 1932. "Capital control" As more and more brutal war of aggression repeated defeat. Start funds control only the capital of more than 500,000 yuan, and need to borrow more than 10 million enterprises; later, more than 20 million of capital and need to borrow more than 5 million corporate control is also listed as an object; in 1940, for general corporate borrowers began to strictly control them. After the Pacific War broke out in 1941, the Japanese and Britain and other countries to freeze other mutual property and international trade cut off, the Japanese trap more isolated, and focus all likely to concentrate financial and material resources for plunder iron, coal, grain and other urgently needed supplies. Puppet Manchuria real estate companies, the puppet Manchukuo agro commune foreign lenders are also collectively managed. Force private banks to expand the deposit, and the deposit of three percent is stored in puppet Manchuria central bank. Companies, businesses, must escalate "Funds need to plan" and "operational reports." Moreover, the central bank set up the puppet Manchukuo enterprises and revocation, increase or decrease of capital, changes in the name of internal expenses, profit distribution and sale of real estate and other personal, involving funding activities are included in the "control "range. "Capital control" of implementation, maintaining the interests of a few monopolies, devastated the National Industry and Commerce.

\section{The Collapse Era of the Financial Control System}

During this period of 1942 --1945 years, the Japanese imperialists was in dead end, they have been extremely difficult in facing an impasse, human, material and financial resources, therefore, the attempt by the implementation of the second "Industrial Development Five-Year Plan" in my Northeast, doubling plunder, to meet the needs of aggression. To this end, the government once again to modify the Manchukuo puppet "Manchukuo Central Bank Law" to increase the puppet Manchuria central bank status, strengthening its role as a State organ. According to the Central Bank of Manchukuo puppet Manchuria government will, faithful implementation of the puppet "Manchukuo basic national policy framework" and "National Savings Law", and according to agriculture "agriculture treasury Law" actively participated in the establishment of pseudo agriculture treasury, will operate its own the transfer of funds to the library supply business, to assist it in controlling all aspects of rural finance, agricultural plunder. Also intensified the implementation of "compulsory savings" to further the implementation of the inflation policy, junk coins, people squeeze blood and sweat; support the expansion of arms production and military industrial relocation, raise military supplies and military supplies.

Table.1 The list of savings indicators and the completion situation in 1942--1945 Unit: million

\begin{tabular}{|c|c|c|c|}
\hline Year & Savings Indicator & Actual Savings & Ratio \% \\
\hline 1942 & 150000 & 116030.4 & $77 \%$ \\
\hline 1943 & 160000 & 164658.8 & $103 \%$ \\
\hline 1944 & 300000 & 373191.3 & $124 \%$ \\
\hline 1945 & 600000 & & \\
\hline
\end{tabular}

Source: Northeast material adjustment committee study group, "Northeast Economy Series (financial papers)," Chinese Culture Service Shenyang Printing, in 37 years, pp. 183-184.

The above table shows, the national savings increased year by year, in 1945, 60 billion of gross national income was $46.2 \%$ of the budget, under hard deductions taken by the Japanese rulers, such as compulsion, any combination of a series of coercive measures, except in 1942, all indicators are exceeded in the rest of the years, due to the defeat of Japan in 1945 but failed to achieve. Only three years between savings amounted to 6,538,805,000 yuan, which undoubtedly aggression of Japan gather a lot of money. 
During this period, the Central Bank of the puppet Manchukuo also focus event completely transferred to the track directly to the services of the war of aggression. Accordingly, it had a larger change in various aspects of their capital, institutional settings and personnel arrangements. Capital from the original 30 million yuan to 100 million yuan; paid-in capital by the amount of 15 million yuan to 25 million yuan. Total branch also has a great change in this period: 1943 to regain part formed (formed in May 1937 has been withdrawn portion) head office 10; since the establishment of the pseudo-agriculture treasury, county-level branch will surrender 82, to hand over all the county grass-roots branches. In addition, according to the 4 "Treasury Department Act" of Central Bank of puppet Manchukuo, the Puppet Government also established the Economic Balance Treasury Department, the Department of Special Property Funds, Special Funds Trading and the Department of Economic Mobilize Funds. These four institutional funds departments of the puppet Manchukuo are disclosed for central bank's foreign business finance in special wartime and their criminal activities are far from the general public institution.

\section{Conclusion}

In summary, the central bank of puppet Manchuria is single-handedly cooked up by the Japanese Kwantung Army, although nominally under the leadership of the Ministry of Economy and Ministry of Manchukuo, but in fact, it was led entirely by the Japanese Imperial Army Command; puppet Manchuria central bank policy, formulate policies and major issues are in accordance with the Japanese colonial policy and planning and the Japanese Kwantung Army's intention to develop its policies and guidelines completely dominated by the Kwantung Army and intervention; puppet Manchuria central bank junk currency is mainly for the Kwantung Army military mobilization in support of its war of aggression against China. Its currency issue and the entire amount of money issued are completely around by the Japanese Imperial Army after manipulation. We can say that the central bank of puppet Manchukuo is financial institution with colonial nature and it was the Japan's financial domination instruments and services for the Japanese financial aggression. Through this article, the central bank of puppet Manchukuo as a "national bank", we cannot peep the whole picture, but at this time the Japanese aggression and plunder of the Northeast can be seen and it is the powerful financial evidence for Japanese aggression. Therefore, the Japanese aggression war is not allowed any question from any country or any individuals, it cannot be avoided and cannot deny the facts, the simply "the Definition of Aggression is Undetermined" cannot be denied.

\section{References}

[1] Zhang Xinzhi. The financial invasion and plundering in half a century - Studies on monetary released by Japanese in our country [M] Beijing: China Financial and Economic Publishing House, 2011.

[2] Qu Zhentao, Zhang Xinzhi. Foreign currency and predatory invasion theory of history [M] Beijing: China Financial and Economic Publishing House, 2007.

[3] A positive history of stable positions. Manchuria central bank decade[M]. Central Bank of Manchuria, Kant nine years (1942)

[4] Financial Research Institute of Jilin Province. Central Bank of Manchukuo historical[M]. Jilin People's Publishing House, 1986.

[5] Manchuria central bank will study the history of the state central bank Man History: currency and financial policies $の$ trajectory [M] Toyo Jingji Shinposha, 1988.

[6] Huang Da. Money and Banking (fourth edition) [M] Beijing: China Renmin University Press, 2009.

[7] Hong Xiaguan. Chinese financial history[M]. Southwest University of Finance and Economics Press, 2001 